\title{
Evaluating effects of electromagnetic fields on the total number and percentage of white blood cells in mice
}

\author{
Bahareh Hormozi ${ }^{1}$, Ali Neamati ${ }^{1}$, Ghorban Safaeian Layen ${ }^{2 *}$, Masoud Homayouni-Tabrizi ${ }^{1}$, Sara Safaeian Laein ${ }^{3}$ \\ ${ }^{1}$ Department of biology, Mashhad Branch, Islamic Azad University, Mashhad, Iran \\ ${ }^{2}$ Department of Technology of Radiology, school of paramedical science, Mashhad University of Medical Science, Mashhad, Iran \\ ${ }^{3}$ Department of Food Hygiene and Aquaculture, Faculty of Veterinary Medicine, Ferdowsi University of Mashhad, Mashhad, Iran
}

*Corresponding Author: Ghorban Safaeian Layen, Department of Technology of Radiology, school of paramedical science, Mashhad University of Medical Science, Mashhad, Iran.

\section{Received Date: June 14, 2021; Accepted Date: June 25, 2021; Published Date: June 30, 2021}

Citation: B Hormozi, A Neamati, G S L M H-Tabrizi, S S Laein. (2021) Evaluating effects of electromagnetic fields on the total number and percentage of white blood cells in mice. J. Cancer Research and Cellular Therapeutics. 5(3); Doi: 10.31579/2640-1053/088

Copyright: (c) 2021 Ghorban Safaeian Layen, This is an open-access article distributed under the terms of the Creative Commons Attribution License, which permits unrestricted use, distribution, and reproduction in any medium,provided the original author and source are credited.

\begin{abstract}
To evaluate the effects of electromagnetic waves on the total number and percentage of white blood cells and also antioxidant effects of vitamin $\mathrm{C}$ on the effects radiation, 24 male mice (Balb/c) were used: control under the influence of low frequency electromagnetic waves and under the influence of waves with vitamin $\mathrm{C}$. Total number of white blood cells in under the influence waves group significantly increased compared to control group, and also under the influence waves group with vitamin $\mathrm{C}$ because its antioxidant property is able to prevent the increasing impact of electromagnetic waves. The percentage of white blood cells in the under influence waves group did not significantly change compared to the control group and also, the under influence waves group with vitamin $\mathrm{C}$ had no significant change compared to the other group. The percentage of neutrophils in samples of the under influence waves group had significant decrease compared to control group but in the under influence waves group with vitamin $\mathrm{C}$ compared to the other group, this vitamin $\mathrm{C}$ could prevent a significant reduction in percentage of neutrophils. Our findings indicated that low electromagnetic fields have caused significant changes in the total number of white blood cells and percentage of neutrophils in mice. In the group that received vitamin $\mathrm{C}$ injection, significant changes were observed in the total number of white blood cells and percentage of neutrophils relative to the group under the influence of low electromagnetic waves, which indicates that vitamin $\mathrm{C}$ could restore the mean total number of white blood cells and percentage of neutrophils to normal value.
\end{abstract}

Keywords: low frequency electromagnetic waves; mice; vitamin c; white blood cells

\section{Introduction}

The electromagnetic field is a field generated by accelerated electrically charged particles. In fact, the interaction of two perpendicular magnetic and magnetic fields creates an electromagnetic field. These twodimensional waves are cross-flows, that is, the energy transfer is perpendicular to the oscillations. In fact, the electric fields created with different voltages and the magnetic fields it produces are called electromagnetic fields. The amount of electromagnetic radiation absorption and penetration depends on the frequency, type of radiation, and the type of tissue that absorbs it. Most of the radiation in our environment seems to be very low frequency electromagnetic radiation and very low frequency electromagnetic radiation that operates at a frequency range of 0 to $300 \mathrm{~Hz}$, and its frequency is constant in everyday human life, in its rising now [1]. White blood cells are made only of lymph nodes and thymus glands; these cells act as bodyguards against invasive external factors. If external bacteria find the skin through the tissues and cause infection, the white blood cells attack and try to encircle the attacker, resulting in a painful vomiting, but infection which usually occurs in this way is limited. If the infection is like an infection with influenza or a more severe disease, such as a common smallpox, the invasion may be successful soon, but these are white blood cells that overcome the virus and in our body permanent immunity against subsequent attacks of this particular factor is created. The white blood cells in the body make immunity, the red blood cells deliver oxygen and food to all the cells of the body, and the platelets prevent us from destroying our blood from bleeding caused by simple cuts [2-4]. The effect of very low frequency magnetic fields on the genome has been investigated in laboratory organisms and different results have been obtained. Some studies have reported increased damage to DNA in 
special circumstance [5]. But others have not confirmed such effects [6]. Most studies on lymphocytes, monocytes, and skeletal muscle cells do not show genetic effects. While some other studies on fibroblasts, melanocytes, and granulosa cells of rats have shown significant effects on electromagnetic fields of varying frequencies [7]. Diem, exposed the human fibroblasts to an alternating magnetic field of $1 \mathrm{~mm}$ Tesla, $50 \mathrm{~Hz}$ for 15 hours, has seen an increase in the fracture of DNA strands [8]. The results of some other studies indicate that a very low frequency magnetic field induces chromosomal damage of polychromatic erythrocytes of bone marrow in Balb/c mice and an increase in the incidence of micronucleus in neonatal neonates in native mice exposed to radiation during electromagnetic fields where the low frequency was located $[9,10]$. Many studies have been presented in connection with disturbances caused by electromagnetic waves such as sterility, unintended abortion of congenital defects, early maturity, and genetic diseases [11].

\section{Material and Methods}

\section{Electromagnetic waves device}

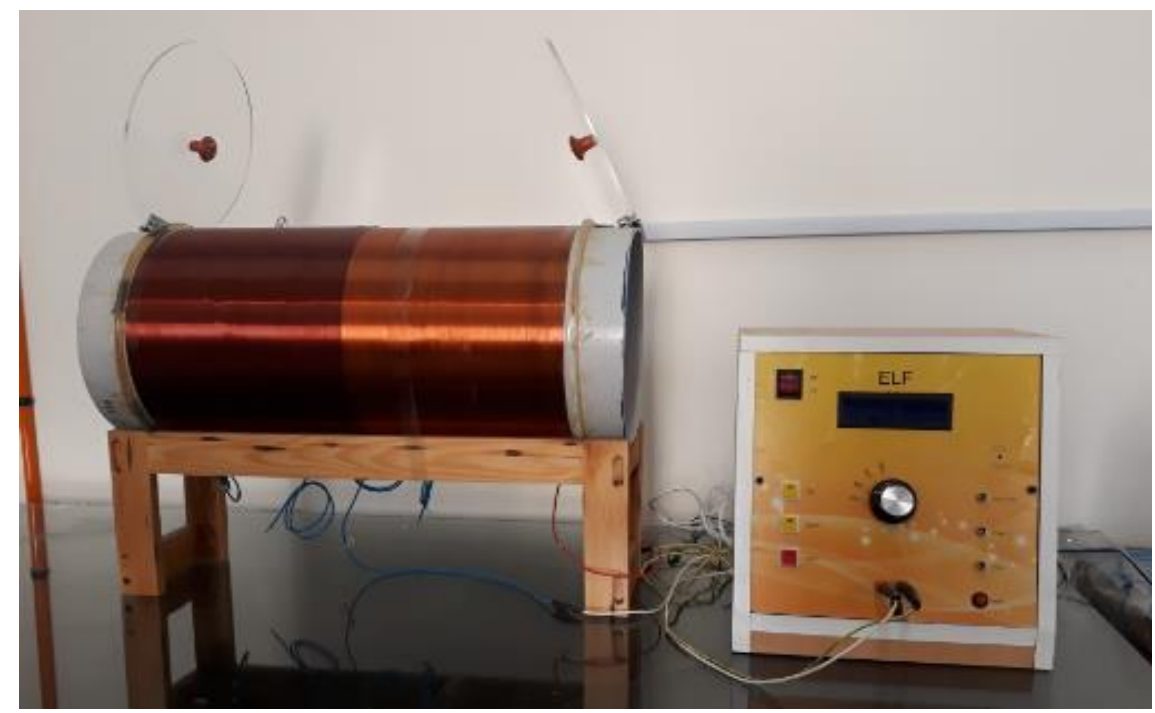

Fig 1. Electromagnetic waves device.

The low electromagnetic wavelength generator consists of a pipe made of pvc diameter 35 and a length of $60 \mathrm{~cm}$, with 1900 rounds of copper lacquered wires lacquered in three floors. This device can produce electromagnetic fields from 0.5 to 4 milliseconds at frequencies from 25 to $100 \mathrm{~Hz}$. In this study, the field of electromagnetism was $4 \mathrm{mT}$ and a frequency of $50 \mathrm{~Hz}$.

\section{Prepration of solutions}

Turk's solution: 3 cc glacial acetic acid, blue violet methylene (small amount), and distilled water $97 \mathrm{cc}$.

Giemsa solution: $8 \mathrm{cc}$ color Giemsa diluted with $100 \mathrm{cc}$ of ordinary water. Method for preparing vitamin C solution: Pour $250 \mathrm{ppm}$ vitamin C tablets into the mortar and dissolve the obtained powder in 50cc sodium chloride injectable serum. The solution was kept far from any light and kept in the refrigerator.

\section{Animal groups}

Mice (Balb/c) were used in this study, male mice weigh 23-25 g were selected for experiments, in the animal room at a temperature of 21-23 ${ }^{\circ} \mathrm{C}$, and a natural cycle of darkness (12 hours Day and 12 o'clock in the evening) and have enough water and food.

In this study, the samples were randomly divided into three groups.

Group 1: Controls maintained in normal conditions in the animal room. $(\mathrm{n}=8)$

Group 2: Exposure to low frequency electromagnetic fields (frequency of $50 \mathrm{~Hz}$, intensity of $4 \mathrm{mT})(\mathrm{n}=8)$

Group 3: Exposure to low frequency electromagnetic fields and vitamin $\mathrm{C}$ received that were injected intraperitoneally every one day with $0.5 \mathrm{cc}$ of vitamin C. $(n=8)$

\section{Blood sampling}

After the test, the samples were anaesthetized with chloroform, and after opening the chest region, about $1 \mathrm{ml}$ of blood was taken from the heart and poured into the $\mathrm{CBC}$ tube. Then, it was shifted in the form of 8 English to blend the blood inside the tube with EDTA to prevent clotting [12].

\section{White Blood Cell Counting}

Blot the EDTA blood sample for one minute and use the sucker to drain the blood to a grade of $0.5 \mathrm{ml}$ and bring to a grade 11 degree of special diluent (thus dilution 1 to 20 of blood). After mixing it for 3 minutes, a drop of solution is poured onto a neobar slab and is counted with a 10microscope lens. 4 squares for the white blood cell and multiply the number obtained by 50 .

\section{WBC smear}

Blood samples are taken from a droplet with a hair follicle tube and placed on a slide by drawing a lamina on the lam, then blood cells are stabilized by adding methanol to the spread of blood. After drying, one milliliter of Giemsa paint was poured over it and after 15 minutes the lam was washed with flowing water and was thoroughly washed. When it dried, then a drop of impregnated oil was applied to a spray-coated stainless steel with a magnification of 100 microscopes. We start counting the types of white blood cells from a lame corner of the zigzag. By counting $100 \mathrm{RBCs}$ and determining each of the types of RBCs in this 100 , each of them is obtained.

\section{Statistical calculations}

For data analysis and statistical surveys, all data are shown as MEAN \pm SEM. SPSS software was used for comparison between control group and experimental groups and Excel software was used for drawing graphs.

\section{Result}




\section{White Blood Cell (WBC)}

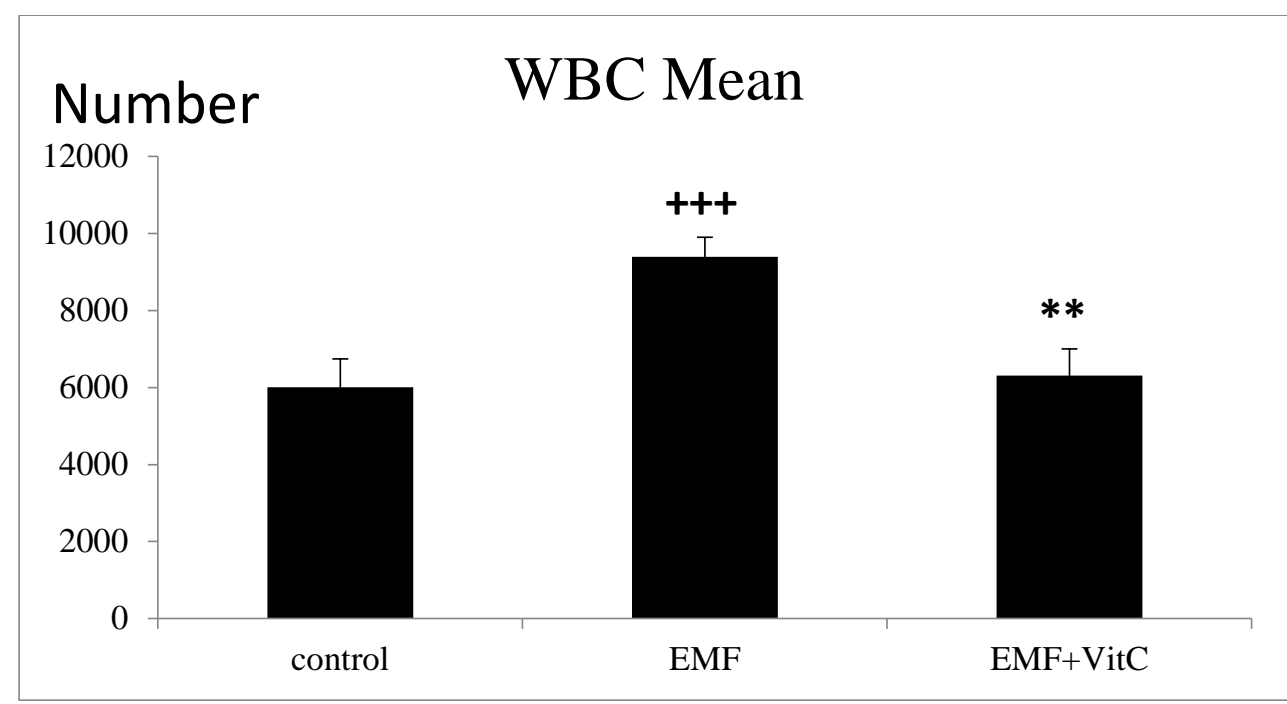

Figure 2: Comparing the number of white blood cells among all the groups.

+++ Significant difference in the range of 0/001 in the waves affected group and control group.

** Significant difference in the range of 0/01 in the waves affected group and the waves affected received vitamin C.

The mean number of white blood cells in the control group was 6012.347 \pm 222 and in the waves affected group 9392.85 \pm 505.73 , there was a significant difference between the two groups $(p<0.05)$. The number of white blood cells in the waves affected with received vitamin $\mathrm{C}$ groups is
$60.95 \pm 12.96$, which is significantly different from that of the affected group $(\mathrm{p}<0.05)$.

\section{Neutrophil}

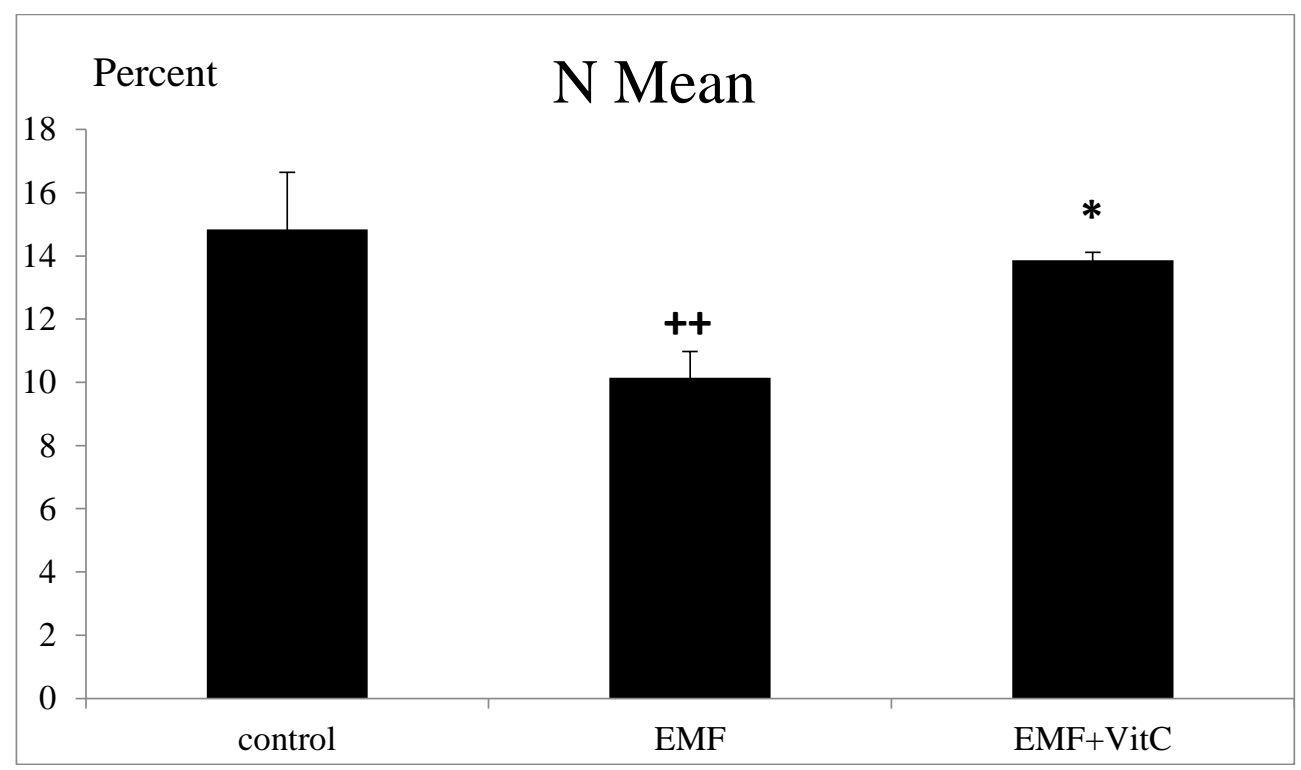

Figure 3: Comparing the number of neutrophils among all the groups.

++ Significant difference in the range of 0/01in the waves affected group and control group.

* Significant difference in the range of 0/05 in the waves affected group and the waves affected received vitamins.

According to the results of this study, the mean blood neutrophil in the control group was $14.83 \pm 1.81$ and in the waves affected group was 10.14 \pm 0.82 , in which there was a significant difference between the two groups $(\mathrm{P}<0.05)$. And in the waves affected group received vitamin $\mathrm{C}$ equal to
$13.85 \pm 0.26$, there is a significant difference between this group and the group affected by the waves.

\section{Lymphocyte}




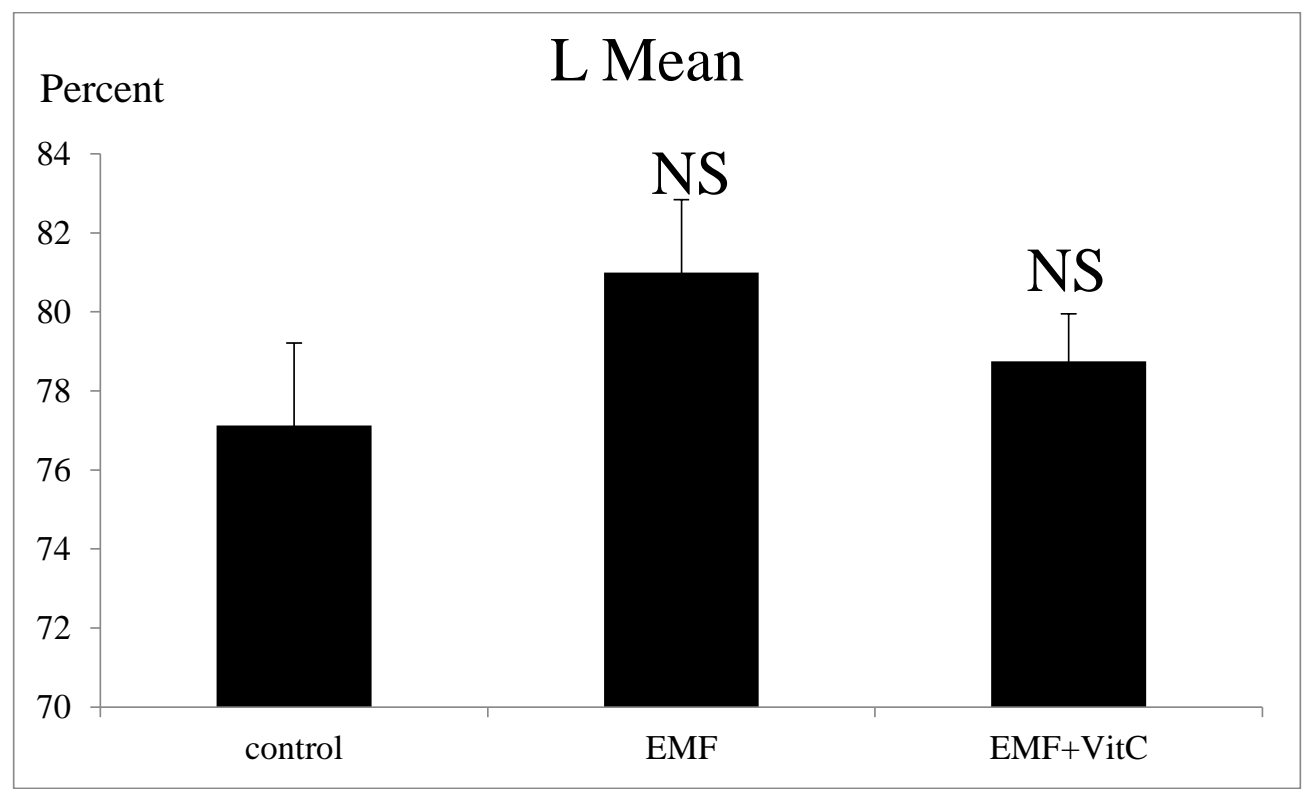

Figure 4: Comparing the number of Lymphocytes among all the groups.

NS showed no significant difference among all the groups.

According to the results, the mean of blood lymphocytes in the control group was $77.12 \pm 2.9$ in the waves affected group, $81.8 \pm 1.83$. There was no significant difference between the two groups. The lymphocyte samples of waves affected with received vitamin $\mathrm{C}$ groups are $78.75 \pm$
1.20, which does not have a significant difference with the group affected by electromagnetic waves.

\section{Monocyte}

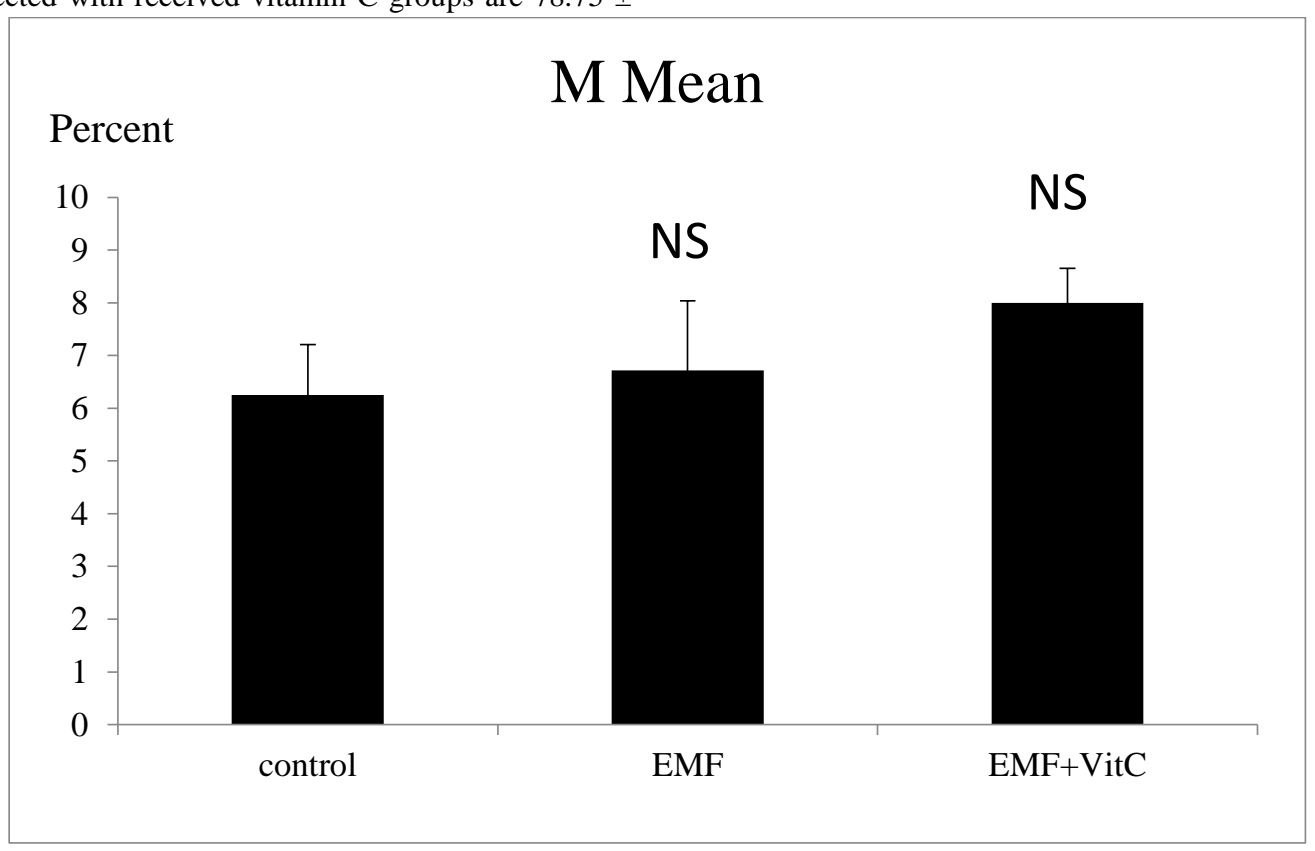

Figure 5: Comparing the number of Monocytes among all the groups.

NS showed no significant difference among all the groups.

According to the results of this study, the mean blood monocyte in control samples was $6.25 \pm 0.95$ and in the waves affected group, it was $71.7 \pm$ 1.32. There was no significant difference between the two groups.
Monocytes under the influence of waves received vitamin $\mathrm{C}$ are $8 \pm 0.65$, which is not significantly different from that of the waves affected group.

\section{Eosinophil}




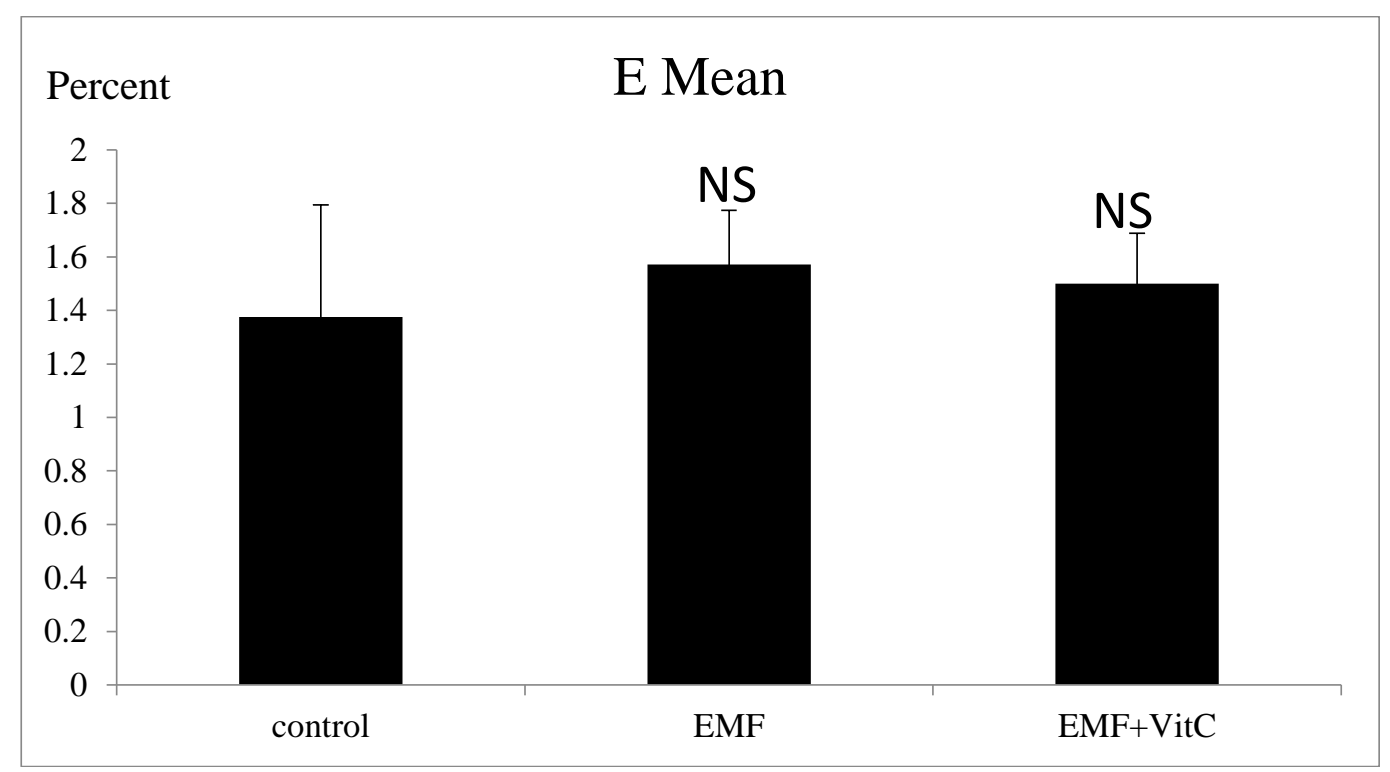

Figure 6. Comparing the number of Eosinophils among all the groups.

NS showed no significant difference among all the groups.

According to the results, the mean blood eosinophil level in the control group was $1.37 \pm 1.41$ and in the waves affected group was $1.57 \pm 0.12$, which showed a significant difference between the two groups was not observed. And in the waves affected group received vitamin $\mathrm{C}$ equal to
$1.5 \pm 0.18$, there is no significant difference between the group and the group affected by the waves.

\section{Basophile}

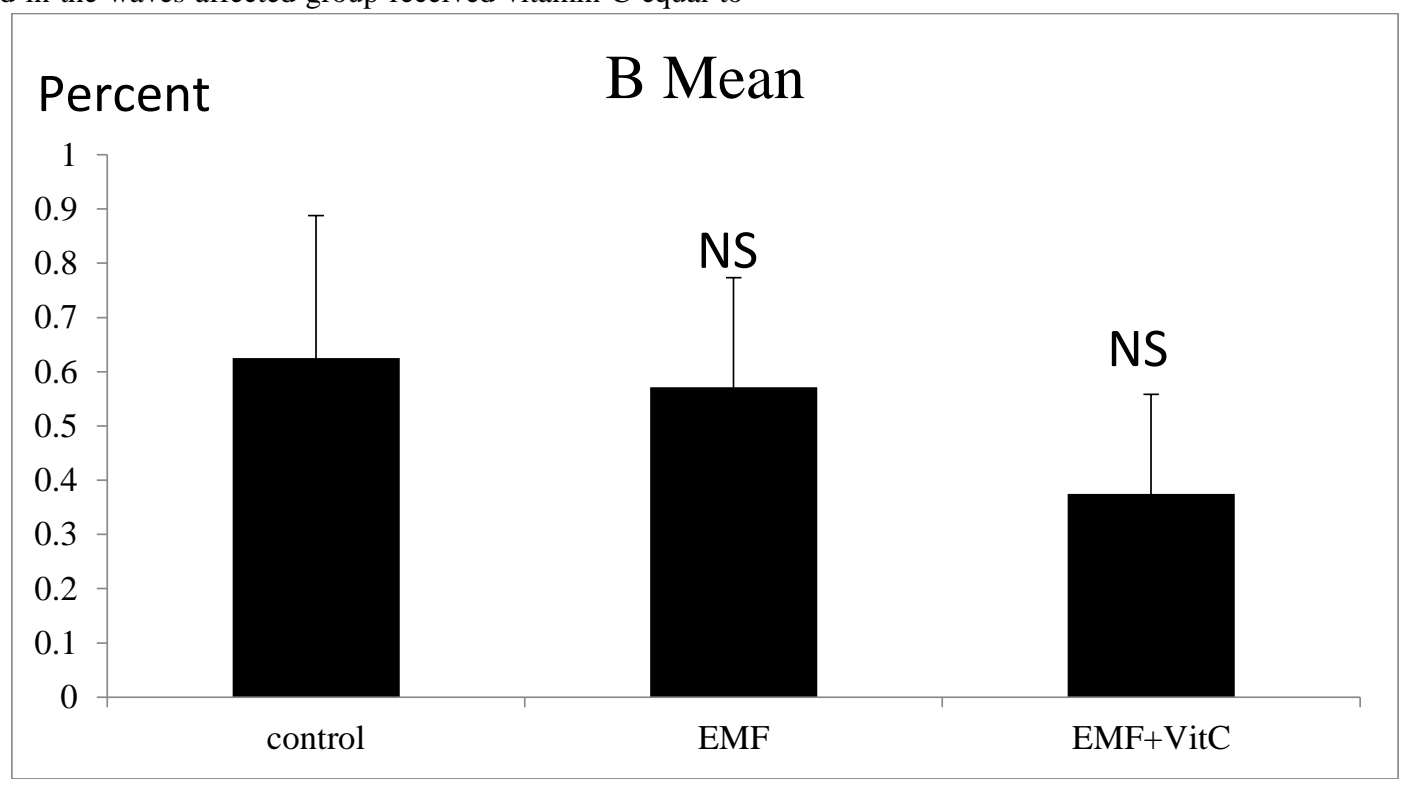

Figure 7. Comparing the number of Basophiles among all the groups.

NS showed no significant difference among all the groups.

According to the results, the mean blood eosinophil level in the control group was $0.62 \pm 0.26$ and in the waves affected group was equal to 0.57 \pm 0.20 , and there was no significant difference between the two groups. The basophile waves affected with received vitamin $C$ equal to $0.37 \pm$ 0.18 , which is not significantly different from that of the affected group.

\section{Discussion}

Several reports have been published on the effects of low frequency electromagnetic fields on biological systems and human health. Some observations indicate that electromagnetic waves affect living organisms and that the function of tissues and biochemical, biophysical and physiological processes such as leukemia, brain tumors, immune deficiency in DNA of somatic cells, and since damage can lead to grow cancer or death of the cell (apoptosis), and in the germ cells will lead to 
mutation and its subsequent transmission, investigating the effects of electromagnetic waves on the genetic content of cells is one of the important studies that has been noted in recent years. Many studies have shown that electromagnetic fields, by changing the function or function of cells, induce many responses in living organisms, including the effects on cell proliferation and differentiation cell, inducing the death of the program cell, intercellular communication impaired and deoxyribonucleic acid abortion, gene expression, increased degradation, production of free radicals and changes in DNA and antioxidant enzyme activity. Several studies have shown on human peripheral blood lymphocytes and mammalian cells. Electromagnetic waves produce oxidative stress and free oxygen radicals that cause body antioxidant defects and increase genotoxic effects, such as chromosomal and aneuploidy instability in DNA. Creating micronucleus is one of the symptoms of chromosomal damage that is used to identify chromosomal aberrations in short-term laboratory research [13].

Studies by Ivana et al in 2004 suggest that it may be possible to reduce the number of WBCs and their percentage to reduce the precursor cells in the bone marrow, which contradicts the results of this study [14-17]. In some studies, it was found that electromagnetic fields resulted in increase the number of WBCs and their percentage (lymphocytes, monocytes, neutrophils, eosinophils, basophils), with increase the total number of white blood cells consistent with the result of this research, but increase in the percentage of its types contradicts this research. Another study was conducted to investigate the effect of $940 \mathrm{MHz}$ electromagnetic fields on the hematopoietic system of immature Balb/c mice. The evaluation of blood samples collected from laboratory and experimental samples showed that the mean number of white blood cells and its percentage (lymphocyte, monocyte, neutrophil, eosinophil, basophil) in the experimental group was not different from the control group $(p<0 / 05)$, which results in contrary to the results of this study, except for the percentage of monocytes, lymphocyte, basophil and eosinophil the percentages of which are consistent in both studies which are consistent with the Selmaoui report. He did not see any changes in the number of white blood cells and the percentage of monocytes, lymphocytes, neutrophils, eosinophils, and basophils, by exposing healthy young men to a $50 \mathrm{~Hz}$ magnetic field. Sommer also had no significant effect on the effects of electromagnetic fields emitted on the white blood cell count of $\mathrm{AKR} / \mathrm{J}$ mice [18]. In another study, two control and experimental groups of adult and immature male rats were placed near the microwave device at a frequency of $2450 \mathrm{MHz}$ The results of this study indicate that in the immature group most of the blood factors were affected by the effects of microwave waves, in this group the number of white blood cells and the percentage of lymphocytes decreased, which contradicted the results of this study. However, the percentage of eosinophils, basophil, neutrophils and monocytes in both adult and immature groups in the waves affected group did not significantly change compared to control which is consistent with the results of this research. Except for neutrophil percentages which contradict the results of both studies. But in the adult group, changes in the mean number and percentage of white blood cells were not significant [19]. While the results of Trosic and et al in 2004 regarding the effect of waves on the number and percentage of white blood cells are consistent with the results of the adult group, they contradict the results in the immature group. The difference in the effects of these waves on blood factors can be related to the age of the exposed person, the frequency of the waves, and the distance from the source of the wave production. In this study, microwave waves can change most of the blood factors studied in immature mice. This effect can be due to the direct effect of the waves on the bone marrow cells or the effect of these waves on the cells in the peripheral blood. The effect of these waves on mice was weaker [20]. Sert and et al in 2000 reported that low-frequency waves had an effect on the immunological and hematologic factors of the electric power plant workers exposed to electromagnetic waves produced from low frequency $50 \mathrm{~Hz}$ power lines. Such as the number of white blood cells and the percentage of its type, which is the result of the total number of white blood cells and its neutrophil fraction contradicts the results of this study. But the results of the percentage of other types of white blood cells are consistent with this research [21].

\section{Conclusion}

In this study, the number of white blood cells in the samples of the affected group was significantly higher than the control group. The percentage of lymphocyte, monocyte, basophil, and eosinophil cells was not significantly different from the control group, but the neutrophils of the group underwent a significant decrease compared to the control group. The total number of white blood cells in the group under the influence of electromagnetic waves receiving the vitamin $\mathrm{C}$ was significantly different from that of the group affected by the waves, and vitamin $C$ has been partially able to prevent the increase of white blood cells. Because of its antioxidant properties, vitamin $\mathrm{C}$ is involved with free radicals and prevents their destructive effects. Percentage of lymphocyte, monocyte, basophil and eosinophil cells in the group under the influence of electromagnetic waves receiving the vitamin $\mathrm{C}$ did not change significantly compared to the group affected by waves, but the percentage of neutrophil cells in this group had a significant decrease compared to the group affected by waves and vitamin $\mathrm{C}$ has somewhat prevented the percentage of these cells from falling.

\section{Acknowledgments}

This article is extracted from Ms.Bahareh Hormozi's Msc thesis, which was conducted at Islamic Azad University, Mashhad Branch. The researchers need to thank the university authorities and staff of the department of biology, who have made this research happen.

\section{Conflicts of Interest}

The authors have not declared potential conflicts of interest with respect to the Declaration of Conflicting Interests.

\section{References}

1. Jiménez-García MN, Arellanes-Robledo J, Aparicio-Bautista DI, Rodríguez-Segura MÁ, Villa-Treviño S, Godina-Nava JJ. (2010) Anti-proliferative effect of extremely low frequency electromagnetic field on preneoplastic lesions formation in the rat liver. BMC cancer ;10(1):159.

2. Black DR, Heynick LN. (2003) Radiofrequency (RF) effects on blood cells, cardiac, endocrine, and immunological functions. Bioelectromagnetics ;24(S6).

3. Hefco V, Maniu C, Hritcu L. (2005) Effects of an weak electromagnetic field upon rat blood parameters. Analele Stiintifice ale Universitatii" Al I Cuza" Din Iasi(Serie Noua) Sectiunea 2 a Genetica si Biologie Moleculara ;6.

4. Abdel-Rahman M. (2004) Effect Of L-Cysteine On Blood Picture And Some Serum Parameters In Rats Exposed To 2 Gauss Electro-Magnetic Field. Egyptian Journal of Hospital Medicine ;17:197-206.

5. Ivancsits S, Diem E, Pilger A, Rüdiger HW, Jahn O. (2002) Induction of DNA strand breaks by intermittent exposure to extremely-low-frequency electromagnetic fields in human diploid fibroblasts. Mutation Research/Genetic Toxicology and Environmental Mutagenesis ;519(1):1-13.

6. Scarfí MR, Sannino A, Perrotta A, Sarti M, Mesirca P, Bersani F. (2005) Evaluation of genotoxic effects in human fibroblasts after intermittent exposure to $50 \mathrm{~Hz}$ electromagnetic fields: a confirmatory study. Radiation research ;164(3):270-6.

7. Ivancsits S, Pilger A, Diem E, Jahn O, Rüdiger HW. (2005) Cell type-specific genotoxic effects of intermittent extremely low- 
frequency electromagnetic fields. Mutation Research/Genetic Toxicology and Environmental Mutagenesis ;583(2):184-8.

8. Ivancsits S, Diem E, Jahn O, Rüdiger HW. (2003) Intermittent extremely low frequency electromagnetic fields cause DNA damage in a dose-dependent way. International archives of occupational and environmental health ;76(6):431-6.

9. Suzuki Y, Ikehata M, Nakamura K, Nishioka M, Asanuma K, Koana T, et al. (2001) Induction of micronuclei in mice exposed to static magnetic fields. Mutagenesis ;16(6):499-501.

10. Tolstikova T, Sorokina I, Tolstikov G, Tolstikov A, Flekhter O. (2006) Biological activity and pharmacological prospects of lupane terpenoids: I. Natural lupane derivatives. Russian Journal of Bioorganic Chemistry ;32(1):37-49.

11. Hetherington H, Pan J, Chu WJ, Mason G, Newcomer B. (1997) Biological and clinical MRS at ultra-high field. NMR in Biomedicine ;10(8):360-71.

12. Yildiz H, Durmus AS, Simsek H. (2011) Surgery-induced changes in red blood cell and plasma lipid peroxidation, enzymatic and non-enzymatic antioxidants, and blood hematology of female rats: protective role of methylene blue and vitamin E. European Journal of Obstetrics \& Gynecology and Reproductive Biology ;155(1):89-93.

13. Baharara J, Haddad F, Ashraf A, SADEGH MAR. (2012) The Antioxidant Effect of Vitamin $\mathrm{C}$ on Decreasing the Induced Chromosomal Damages by Low-Frequency Electromagnetic Field on Bone Marrow Erythrocytes of Male Balb/C Mouse.

14. Trošić I. (2001) Multinucleated giant cell appearance after whole body microwave irradiation of rats. International journal of hygiene and environmental health ;204(2-3):133-8.
15. Bonhomme-Faivre L, Marion S, Bezie Y, Auclair H, Fredj G, Hommeau C. (1998) Study of human neurovegetative and hematologic effects of environmental low-frequency $(50-\mathrm{Hz})$ electromagnetic fields produced by transformers. Archives of Environmental Health: An International Journal ;53(2):87-92.

16. Tofani S, Ferrara A, Anglesio L, Gilli G. (1995) Evidence for genotoxic effects of resonant ELF magnetic fields. Bioelectrochemistry and Bioenergetics ;36(1):9-13.

17. Zotti-Martelli L, Peccatori M, Scarpato R, Migliore L. (2000) Induction of micronuclei in human lymphocytes exposed in vitro to microwave radiation. Mutation Research/Genetic Toxicology and Environmental Mutagenesis ;472(1):51-8.

18. Sommer AM, Bitz AK, Streckert J, Hansen VW, Lerchl A. (2007) Lymphoma development in mice chronically exposed to UMTSmodulated radiofrequency electromagnetic fields. Radiation research ;168(1):72-80.

19. A T. (2006) Abij Medical Physic ;6th ed(423):28.

20. Jelodar G, Zare Y, Ansari M, Nazifi S. (2008) Effect of radiation leakage of microwave oven on hematological parameters of rat at pre and post pubertal Stage. Zahedan Journal of Research in Medical Sciences ;10(4):0.

21. Dasdag S, Sert C, Akdag Z, Batun S. (2002) Effects of extremely low frequency electromagnetic fields on hematologic and immunologic parameters in welders. Archives of medical research ;33(1):29-32.

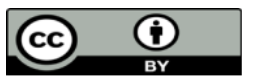

This work is licensed under Creative Commons Attribution 4.0 License

To Submit Your Article Click Here: Submit Manuscript

DOI: $10.31579 / 2640-1053 / 088$
Ready to submit your research? Choose Auctores and benefit from:

* fast, convenient online submission

* rigorous peer review by experienced research in your field

* rapid publication on acceptance

* authors retain copyrights

* unique DOI for all articles

* immediate, unrestricted online access

At Auctores, research is always in progress.

Learn more www.auctoresonline.org/journals/cancer-research-andcellular-therapeutics 